\author{
Karina Knasiecka-Falbierska \\ Wyższa Szkoła Techniczno-Humanistyczna „Kadry dla Europy” w Poznaniu \\ E-MAIL: karina.poz@interia.pl
}

\title{
Posłusznie o nieposłuszeństwie - czyli anarchista w szkole
}

\begin{abstract}
STRESZCZENIE
Nieposłuszeństwo to jedna z cech wyróżniająca grupę anarchistów spośród innych subkultur młodzieżowych. Wyróżniają ją również nastawienie do szkoły. Podstawową wartością jest tu szeroko pojmowana wolność jednostki. Analiza literatury i czasopism anarchistycznych pozwalała przypuszczać, iż uczniowie anarchiści na terenie szkoły mogą stosować różne formy oporu, kontestując władzę oraz znaczenie kultury szkolnej.

Wyniki przeprowadzonych przeze mnie badań z uczniami liceów wykazały, że jest inaczej. Otóż badani przyjmują istnienie szkoły i przymus chodzenia do niej, niezależnie od stopnia zaangażowania $\mathrm{w}$ ruch, pragmatycznie, jako szczebel edukacji konieczny do realizacji dalszych planów życiowych. Jest ona dla nich instytucją, przez którą należy przejść najniższym kosztem. Ich krytyka szkoły i jej kultury przejawia się tylko w warstwie deklaratywnej, a nie działaniowej.
\end{abstract}

SŁOWA KLUCZOWE: opór, młodzież, anarchiści, szkoła.

Nieposłuszny oznacza 'niespełniający poleceń, niesłuchający rozkazów, krnąbrny, oporny’1 i właśnie te cechy są przypisywane przedstawicielom ruchu anarchistycznego. Zwalczanie autorytetu we wszystkich formach władzy, przymusu czy hierarchii to jedna z podstawowych idei tego ruchu². Wśród jego przedstawicieli znajdują się młodzi ludzi, którzy mogą uczęszczać do szkoły, jednej z przymusowych instytucji zwalczanych przez anarchistów. I tu rodzi się szereg pytań dotyczących funkcjonowania młodych anarchistów

Słownik języka polskiego, t. 2, L-P, Państwowe Wydawnictwo Naukowe, Warszawa 1979, s. 350 .

2 D. Grinberg, Ruch anarchistyczny w Europie Zachodniej 1870-1914, Wydawnictwo Naukowe PWN, Warszawa: 1994; R. Tokarczyk, Współczesne doktryny polityczne, Zakamycze, Kraków 2002; J. Janicki, Lewacy. Historia i współczesność ekstremistycznej lewicy, Książka i Wiedza, Warszawa 1981. 
- uczniów w szkole: czy uczniowie anarchiści na terenie szkoły stosują różne formy opory? Czy kontestują władzę oraz znaczenie kultury szkolnej? Czy może do edukacji i uczęszczania do szkoły podchodzą pragmatycznie? Na te pytania udzielę odpowiedzi, odwołując się do wyników badań nad anarchistami uczniami liceów ${ }^{3}$.

\section{Anarchiści o edukacji}

Skierowanie uwagi pedagoga na środowisko anarchistyczne wiąże się z założeniami ideologicznymi tego ruchu i wynikającą z nich niechęcią do instytucji szkolnej i obowiązku uczęszczania do niej.

Wartością podstawową, fundamentem wszelkich założeń tego ruchu dotyczących rzeczywistości społeczno-polityczno-ekonomicznej jest szeroko pojmowana wolność jednostki. Jest ona warunkiem istnienia autonomicznego, spontanicznego, kreatywnego działania jednostki i grupy społecznej ${ }^{4}$. Ruch ten neguje potrzebę i zasadność istnienia państwa i wszelkich jego instytucji (w tym również szkoły) jako form ograniczających wolność jednostki. Z tego dążenia do wolności wyrasta bunt przeciwko szkole jako instytucji i niechęć do obowiązku szkolnego. Bunt jest silniejszy ponieważ zaplecze społeczne ruchu stanowi zazwyczaj młodzię̇ ${ }^{5}$.

Anarchiści nie tylko krytykują istniejące instytucje, ale również domagają się ich zniesienia lub zmiany. Ich postulaty dotyczą wszystkich sfer życia społecznego, w tym również edukacji i szkoły. Klasyczni anarchiści krytykowali instytucje edukacyjną za reprodukowanie systemu burżuazyjnego w programach nauczania i zasobie wiedzy. Kolejnym krytykowanym jej elementem był również przymus i władza szkolna posługująca się jego tradycyjnymi środkami, systemem kar i nagród dla podtrzymania dyscypliny. Anarchiści nie tylko krytykowali edukację, ale mieli również praktyczne projekty jej zmiany tak, aby była ona, po pierwsze, dostępna dla wszystkich, a po drugie, zapewniała swobodę i nie ograniczała wolności uczęszczającym do instytucji edukacyjnej ${ }^{6}$.

3 Badania przeprowadzone w ramach pracy doktorskiej Doświadczanie codzienności szkolnej przez młodych anarchistów, napisanej pod kierunkiem naukowym prof. M. Dudzikowej, obronionej w 2005 na Wydziale Studiów Edukacyjnych na Uniwersytecie im. Adama Mickiewicza w Poznaniu. Rozprawa doktorska jest podstawą opublikowanej monografii Codzienność szkolna $w$ doświadczeniach młodych anarchistów. Analiza przypadków, Unidruk, Poznań 2007.

4 D. Grinberg, Ruch anarchistyczny..., s. 82-83; R. Tokarczyk, Współczesne doktryny..., S. 271.

5 R. Antonów, Pod czarnym sztandarem. Anarchizm w Polsce po 1980 roku, Wydawnictwo Uniwersytetu Wrocławskiego, Wrocław 2004.

6 J. Zieliński, Czy w Polsce anarchizm ma rację bytu?, Zielona Góra 1998 - przedruk w formie broszury; D. Grinberg, Kultura anarchistyczna i świat wartości, „Mać Pariadka” 1994, 
Szkoła, zdaniem dzisiejszych anarchistów, podobnie jak ich poprzedników, powinna być wolna od administracji państwowej i jakiejkolwiek indoktrynacji. Jest ujmowana jako element systemu społecznego, jako narzędzie socjalizacji i utrwalania dominującego wzoru kulturowego. Odrzucają oni szkołę jako instytucję dbającą o ideologiczne interesy państwa, jako narzędzie reprodukcji istniejącego systemu i kultury. W konsekwencji jest ona miejscem ciągłego konfliktu między nauczycielem a uczniem, jest również miejscem oporu młodych anarchistów wobec władzy nauczyciela, nudnego i ograniczającego programu nauczania, wymagań szkolnych przeszkadzających w rozwoju ucznia. Szkoła powinna być względnie autonomiczna, a w rozumieniu anarchistów jest narzuconym obowiązkiem i miejscem łamania praw uczniów ${ }^{7}$. W tej perspektywie fantastyczną bronią przeciwko szkole są, zdaniem jednego anarchisty, wagary ${ }^{8}$. To dzięki nim uczeń zdobywa wiedzę o życiu.

Zatem odpowiedzią młodych anarchistów na codzienność szkolną, jeśli do niej uczęszczają, powinno być nieposłuszeństwo i opór, ponieważ jest on wpisany wideologię anarchistyczną. Szkoła powinna być dla nich obcym światem, w stosunku do którego powinni (mogliby) stosować różne formy oporu. Oporu rozumianego zgodnie z teorią Henry'ego A. Giroux i Petera McLarena (w podobny sposób ujmującej szkołę jak współcześni anarchiści), w której oznacza on „opozycyjne zachowanie” uczniów, konstatujące władzę oraz znaczenie kultury szkolnej i jest usytuowany w perspektywie emancypacyjnej ${ }^{9}$. Zachowania emancypacyjne zmierzać powinny do uwolnienia się od zależności, np. od nauczycieli, oraz konfrontowania i odrzucania różnych form nacisku, z którymi spotykają się w szkole. W swym zachowaniu przejawialiby również niedostosowanie do wymagań szkolnych bądź poszukiwaliby własnych rozwiązań ${ }^{10}$. Opór uczniów może przybierać różne formy: od oporu sformalizowanego lub nie, aktywnego lub biernego, jawnego lub utajonego, symbolicznego, ideologicznego i inne. Opór służy McLarenowi do pod-

nr 1; idem, Ruch anarchistyczny...

7 K. Stasiuk, Anarchizm jako krytyka kultury w tekstach trzeciego obiegu z lat osiemdziesiatych i dziewięćdziesiątych, „Kultura i Społeczeństwo” 1999, nr 2; M. Kwaterko, Nieustające wakacje, „Mać Pariadka” 2002, nr 3; Płaszczyzna Większościowa Federacji Anarchistycznej: http://www.fa.most.org.pl/ (oficjalna strona internetowa FA, 2001 rok).

$8 \quad$ M. Kwaterko, Nieustajace wakacje...

9 H. A. Giroux, Reprodukcja, opór i akomodacja, [w:] Nieobecne dyskursy, Z. Kwieciński (red.), cz. 1, Wydawnictwo Uniwersytetu Mikołaja Kopernika, Toruń 1991; P. McLaren, Rytualne wymiary oporu - błaznowanie i symboliczna inwersja, [w:] ibidem.

10 M. Czerepaniak-Walczak, Między dostosowaniem a zmianą. Elementy emancypacyjnej teorii edukacji, Uniwersytet Szczeciński, Szczecin 1994; eadem, Pedagogika emancypacyjna, Gdańskie Wydawnictwo Psychologiczne, Gdańsk 2006. 
kreślania indywidualnego rozwoju emocjonalnych dążeń uczniów, których spontaniczność wykracza poza przyjęte ramy reakcji i zachowania ${ }^{11}$.

\section{Oporni czy posłuszni? - w świetle wyników badań}

Przystępując do badań, stawiałam sobie dwa zamierzenia. Pierwszym było scharakteryzowanie biografii młodych uczestników ruchu anarchistycznego oraz zbadanie stopnia ich zaangażowania w ruch poza szkołą. Drugie zamierzenie dotyczyło odtworzenia, opisania i przeanalizowania sposobów doświadczania codzienności szkolnej przez uczniów anarchistów.

Takie podejście wymagało przyjęcia pewnych założeń teoretycznych oraz wynikającego $\mathrm{z}$ nich sposobu definiowania podstawowych kategorii pojęciowych. Interesowała mnie perspektywa działającego podmiotu oraz jego sposoby doświadczania codzienności szkolnej, co lokowało moje badania na gruncie podejścia jakościowego, w tzw. paradygmacie interakcyjnym, a dokładniej na gruncie fenomenologii.

Podstawową kategorią było doświadczanie. Na podstawie założeń fenomenologicznych $\mathrm{w}$ badaniach przyjęłam rozumienie doświadczania jako procesu składającego się z: spostrzeżeń (organizacji danych zmysłowych), przeżyć, czyli stanów emocjonalno-uczuciowych jednostki, oraz zachowań jednostki, a wszystkie te elementy odnoszą się do „tu i teraz"12.

W związku ze specyfiką obszaru badawczego jako metodę badawczą wybrałam analizę przypadków. Dobór próby badawczej był celowy. Badaniami objęłam uczniów szkół średnich zaangażowanych w ruch anarchistyczny. Badanych dobrałam wśród osób, które same siebie określiły anarchistami i przynajmniej pół roku były związane w jakikolwiek sposób z ruchem anarchistycznym. Ostatecznie próba liczyła sześć osób, w wieku 17-19 lat, $z$ trzech różnych miast (Łodzi, Lublina i Gdańska).

$\mathrm{W}$ toku analiz biografii badanych wyróżniłam trzy typy zaangażowania w ruch anarchistyczny - zaangażowany, słabo zaangażowany, niezaangażowany - i odpowiadające im cztery typy doświadczania codzienności szkolnej. W dalszej części tekstu skoncentruję się tylko na przedstawieniu wyników świadczących o nieposłuszeństwie anarchistów w szkole lub jego braku.

${ }^{11}$ A. Dubik, Konteksty „oporu”. (Między klasykq i myśla wspótczesna), „Socjologia Wychowania" 1997, nr XIII, s. 236; idem, Filozofia i opór, Wydawnictwo Uniwersytetu Mikołaja Kopernika, Toruń 2003.

12 Doświadczenie, T. Buksiński (red.), Wydawnictwo Naukowe Instytutu Filozofii UAM, Poznań 2001; K. Popielski, Neotyczny wymiar osobowości. Psychologiczna analiza poczucia sensu życia, Wydawnictwo Katolickiego Uniwersytetu Lubelskiego, Lublin 1993; Rozwój psychiczny człowieka w ciagu życia, M. Tyszkowa (red.), Państwowe Wydawnictwo Naukowe, Warszawa 1988. 
Jak już wcześniej napisałam, z założeń ruchu anarchistycznego i jego podejścia do obowiązkowej edukacji w instytucji szkolnej wynikało, że uczniowie identyfikujący się ztą ideologią powinni na terenie szkoły przejawiać nieposłuszeństwo i opór w stosunku do władzy we wszelkich formach. Powinni protestować np. przeciwko zależności wobec nauczyciela i wszelkim formom nacisku. Sprzeciw ten powinien być tym większy, im bardziej uczeń identyfikuje się z ideologią anarchistyczną.

Tymczasem, jak wynika $\mathrm{z}$ badań, przez wszystkich badanych (niezależnie od stopnia zaangażowania) szkoła i jej istnienie w społeczeństwie oraz konieczność chodzenia do niej, jest odbierane jako zwyczajny element życia młodego człowieka, przez który każdy musi przejść. Godzą się z tym obowiązkiem i ze wszystkimi jego konsekwencjami, a więc z uczęszczaniem do nielubianej instytucji, podporządkowaniem się nieakceptowanym wymaganiom oraz poddawaniem się władzy nauczyciela. Obowiązek ten jest przez nich wykonywany bez większego sprzeciwu. Zatem ich bunt przeciwko szkole jest pozorny bądź ograniczony do negacji pewnych jej elementów. Świadczą o tym ich działania na jej terenie, zgodne z wymogami tej instytucji, a o buncie świadczą tylko sporadycznie podejmowane próby sprzeciwu. Te sporadyczne czynne akty oporu ${ }^{13}$ przyjmują jedynie postać dyskusji czy otwartych konfliktów z nauczycielami.

Badani anarchiści nie stosują również wagarów, jednej z popieranych przez anarchistów formy walki z instytucją szkolną. Jeśli opuszczają szkołę, to tylko dlatego, że nie podoba im się zachowanie nauczycieli. Najczęściej jednak rezygnują z wagarów z obawy przed zaległościami w nauce. Swym postępowanie i doświadczaniem szkoły badani nie wyróżniają się więc znacząco spośród innych uczniów.

Ich bunt przeciwko szkole i odczuwany pewnego rodzaju dysonans poznawczy jest najbardziej widoczny w warstwie językowej. Większość badanych opisując codzienność szkolną, odwołuje się do terminologii wojennej. Terminologia ta pojawia się $\mathrm{w}$ wypowiedziach charakteryzujących nauczycieli i ich relacje z uczniami oraz relacje z rówieśnikami. Nauczyciele pojmowani są zatem m.in. jako „wredne pały”, a „między rówieśnikami panuje” „czysta wrogość po prostu i nienawiść".

Szkoła jawi się tu jako miejsce walki dwóch wrogich obozów, w jednym ujęciu wrogami są nauczyciele i uczniowie, w drugim naprzeciwko siebie stoją dwie grupy rówieśników. Dla wszystkich badanych szkoła jest więc

13 Między innymi: P. L. McLaren, Rytualne wymiary oporu...; L. Witkowski, $W$ kwestii oporu o pedagogice polskiej (preliminaria w oczekiwaniu na przełom), [w:] Przestrzenie oporu w edukacji, E. Bilińska-Suchanek (red.), Pomorska Akademia Pedagogiczna, Toruń 2006. 
miejscem zmagań bądź to z nauczycielami, bądź z uczniami; jest rzeczywistością, z którą jakoś trzeba sobie poradzicín ${ }^{14}$.

Czy takie ujęcie szkoły jest tylko charakterystyczne dla uczniów-anarchistów? Z przykładów analiz gwary uczniowskiej wynika, że inni uczniowie również opisują szkołę w kategoriach nadzoru, władzy czy walki ${ }^{15}$. Zachowania nauczycieli przedstawiają w kategorii wojny i walki na froncie lub działań wojskowych. Szkoła jest również ujmowana jako koszary wojskowe ${ }^{16}$, instytucja, która nie wymaga twórczego działania i indywidualnych pomysłów. Od ponad dwudziestu lat badania wykazują, że uczniowie nie czują się w szkole dobrze, a winą za to obciążają nauczycieli ${ }^{17}$.

Badani uczniowie anarchiści na terenie szkoły, mimo sporadycznych aktów oporu, nie wykazują się rażącym nieposłuszeństwem i niedostosowaniem do obowiązujących norm. W swoim działaniu w szkole, mimo prób realizacji i demonstracji idei anarchistycznych, nie wyróżniają się specjalnie działaniem. Ich sporadyczna krytyka szkoły i jej kultury, choć zgodna z podzielanymi przez nich ideami, przejawia się tylko w warstwie deklaratywnej, a nie działaniowej.

Tu można się zastanawiać, dlaczego pomimo zaangażowania i znajomości idei ruchu zdecydowanie nastawionego na nieposłuszeństwo w działaniach młodych jego uczestników jest brak oporu, a za to pojawia się posłuszeństwo, konformizm, a nawet pragmatyzm? Próbując odpowiedzieć na to pytanie można zwrócić uwagę na wiele aspektów. Ograniczę się do kilku.

Jedną z przyczyn braku zdecydowanego nieposłuszeństwa i oporu przeciwko instytucji szkolnej w postawie badanych może być ich powód/motyw zaangażowania w idee ruchu. Mimo dość wysokiego (w 3 przypadkach) stopnia zaangażowania badanych, ich przynależność do ruchu mogła być podyktowana nie głęboką identyfikacją z jego ideami, lecz fascynacją sposobem odbierania rzeczywistości i poszukiwania możliwości zaangażowania oraz działania. Wybrali oni grupę o podobnym im światopoglądzie; grupę, która w obliczu kultury konsumpcji i wszechogarniającego pędu ku sukcesowi,

${ }^{14}$ K. Knasiecka-Falbierska, Codzienność...

15 K. Czarnecka, H. Zgółkowa, Słownik gwary uczniowskiej, SAWW, Poznań 1991.

16 D. Chętkowski, Z budy. Czyli spuścić ucznia z łańcucha?, Wydawnictwo Literackie, Kraków 2003; M. Wojciechowska, Wspótczesna szkoła w opinii uczniów i rodziców, [w:] Tożsamość osobowa a tożsamości społeczne. Wyzwania dla edukacji XXI wieku, T. Bajkowski, K. Sawicki (red.), Trans Humana Wydawnictwo Uniwersyteckie, Białystok 2001.

17 J. Kośmider, Relacje uczniów i nauczycieli, [w:] Dzisiejsza młodzież. Stereotypy i rzeczywistość po 1989 roku, B. Fatyga, A. Tyszkiewicz (red.), Wydawnictwo ITE, Radom 1997; M. Dudzikowa, Mit o szkole jako miejscu „wszechstronnego rozwoju” ucznia. Eseje etnopedagogiczne, Wydawnictwo Impuls, Kraków 2001. 
odrzuca dominującą kulturę i towarzyszącą jej świadomośćc ${ }^{18}$ bazującą na wartościach odmiennych od dominujących w dzisiejszej kulturze, gdzie pod-

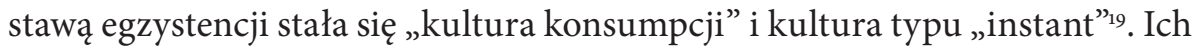
zaangażowanie będzie się więc wiązało tylko z jednym z etapów poszukiwania swojej tożsamości i może być przejściowe ${ }^{20}$. Badani, osoby w okresie dorastania (17-19 lat), który cechuje się niepewnością, a co za tym idzie - poszukiwaniem własnej tożsamości, eksperymentują z różnymi stylami i drogami życia. Otwarci są na różne idee i wszelkiego rodzaju wartości ${ }^{21}$.

Szukanie przez badanych kontaktu z osobami o podobnym światopoglądzie może być nie tylko związane $\mathrm{z}$ okresem adolescencji i poszukiwaniem tożsamości, ale również podyktowane potrzebą przynależenia do konkretnej grupy, społeczności. Dążenie do wspólnoty z ludźmi wyznającymi podobne poglądy może wynikać z „trybalizmu”, który w ujęciu Michela Maffesoliego jest dążeniem do wspólnoty, więzi uczuciowej i identyfikacji z innymi ludźmi ${ }^{22}$. Ruch jest dla badanych formą „nowoplemienia” ${ }^{23}$, które zapewnia im komfort i radość przynależenia oraz umożliwia zaspokojenie potrzeby kontaktu z ludźmi niemającymi w uczestniczeniu w nim konkretnego interesu. Dla młodego anarchisty uczestniczenie w ruchu jest sposobem zaspokojenia potrzeby posiadania „czegoś swojego”.

Brak zdecydowanego oporu i licznych działań związanych z realizacją idei anarchistycznych na terenie szkoły może wynikać z tego, że uczniowie $\mathrm{ci}, \mathrm{z}$ jednej strony negują potrzebę istnienia instytucji, ale $\mathrm{z}$ drugiej ją afirmują. Na jej terenie pragmatyczne podejście do nauki ma przewagę nad ich wartościami ideologicznymi, moralnymi oraz uczuciami osobistymi ${ }^{24}$. Większość badanych (cztery osoby) swoją karierę zawodową po ukończeniu szkoły

18 Między innymi: D. Grinberg, Kultura anarchistyczna; J. Janicki, Lewacy. Historia i....; J. P. Waluszko, Ruch Społeczeństwa Alternatywnego, Man-Gala Press, Sopot 1992.

19 Z. Melosik, Młodzież w kulturze wspótczesnej. Paradoksy pop-tożsamości, [w:] Pedagogika i edukacja wobec nowych wspólnot i różnic w jednoczacej się Europie, E. Malewska, B. Śliwerski (red.), Wydawnictwo Impuls, Kraków 2002; idem, Kultura instant-paradoksy poptożsamości, [w:] Pedagogika u progu trzeciego tysiąclecia, A. Nalaskowski, K. Rubach (red.), Wydawnictwo Uniwersytetu Mikołaja Kopernika, Toruń 2001.

20 H. M. Griese, Socjologiczne teorie młodzieży. wprowadzenie, przekł. J. Dąbrowski, Wydawnictwo Impuls, Kraków 1996; E. H. Erikson, Dopetniony cykl życia, przekł. A. Gomola, Wydawnictwo Rebis, Poznań 2002.

${ }^{21} \quad$ P. Szczukiewicz, Rozwój psychospołeczny a tożsamość, Wydawnictwo Uniwersytetu Marii Curie-Skłodowskiej, Lublin 1998; E. H. Erikson, Dopetniony cykl...

${ }_{22}$ M. Maffesoli, Czas plemion. Schyłek indywidualizmu w społeczeństwach współczesnych, przekł. M. Bucholz, Wydawnictwo Naukowe PWN, Warszawa 2008.

23 Ibidem.

24 P. McLaren, Antystruktura oporu, [w:] Nieobecne dyskursy, Z. Kwieciński (red.), cz. 2, Wydawnictwo Uniwersytetu Mikołaja Kopernika, Toruń 1992. 
i zdaniu matury, wiązała ze studiami. Szkoła średnia stanowi więc dla nich jedną z dróg do przyszłości.

Podsumowując powyższe rozważania, można uznać, że badani uczniowie nie wnoszą do szkoły swoich poglądów, zostawiają je na czas spędzany poza szkołą, a sposób działania w szkole w niewielkim zakresie wiąże się z podzielaną ideologią, ale raczej z uwarunkowaniami osobowościowymi. W dzisiejszym świecie, w którym dominuje pragmatyczne nastawienie do nauki i wykształcenia, uczniowie anarchiści na terenie szkoły wykazują się działaniami konformistycznymi, a szkoła jest dla nich jednym z etapów drogi prowadzącej do zdobycia dobrej pracy.

\section{BIBLIOGRAFIA}

Antonów R., Pod czarnym sztandarem. Anarchizm w Polsce po 1980 roku, Wydawnictwo Uniwersytetu Wrocławskiego, Wrocław 2004.

Chętkowski D., Z budy. Czyli spuścić ucznia z łańcucha?, Wydawnictwo Literackie, Kraków 2003.

Czarnecka K., Zgółkowa H., Słownik gwary uczniowskiej, SAWW, Poznań 1991.

Czerepaniak-Walczak M., Między dostosowaniem a zmianą. Elementy emancypacyjnej teorii edukacji, Wydawnictwo Naukowe Uniwersytetu Szczecińskiego, Szczecin 1994.

Czerepaniak-Walczak M., Pedagogika emancypacyjna, Gdańskie Wydawnictwo Psychologiczne, Gdańsk 2006.

Doświadczenie, T. Buksiński (red.), Wydawnictwo Naukowe Instytut Filozofii UAM, Poznań 2001.

Dubik A., Filozofia i opór, Wydawnictwo Uniwersytetu Mikołaja Kopernika, Toruń 2003.

Dubik A., Konteksty „oporu”. (Między klasyką i myślą współczesną), „Socjologia Wychowania” 1997, $\mathrm{nr}$ XIII.

Dudzikowa M., Mit o szkole jako miejscu „wszechstronnego rozwoju” ucznia. Eseje etnopedagogiczne, Oficyna Wydawnicza Impuls, Kraków 2001.

Erikson E. H., Dopełniony cykl życia, przekł. A. Gomola, Wydawnictwo Rebis, Poznań 2002.

Giroux H. A., Reprodukcja, opór i akomodacja, [w:] Nieobecne dyskursy, Z. Kwieciński (red.), cz. 1, Wydawnictwo Uniwersytetu Mikołaja Kopernika, Toruń 1991.

Griese H. M., Socjologiczne teorie młodzieży, wprowadzenie, przekł. J. Dąbrowski, Oficyna Wydawnicza Impuls, Kraków 1996.

Grinberg D., Ruch anarchistyczny w Europie Zachodniej 1870-1914, Wydawnictwo Naukowe PWN, Warszawa 1994.

Grinberg D., Kultura anarchistyczna i świat wartości, „Mać Pariadka” 1994, nr 1.

Janicki J., Lewacy. Historia i współczesność ekstremistycznej lewicy, Książka i Wiedza, Warszawa 1981.

Knasiecka-Falbierska K., Codzienność szkolna $w$ doświadczeniach młodych anarchistów. Analiza przypadków, Wydawnictwo Uni-druk, Poznań 2007.

Kośmider J., Relacje uczniów i nauczycieli, [w:] Dzisiejsza młodzież. Stereotypy i rzeczywistość po 1989 roku, B. Fatyga, A. Tyszkiewicz (red.), Wydawnictwo ITE, Radom 1997.

Kwaterko M., Nieustające wakacje, „Mać Pariadka” 2002, nr 3.

Maffesoli M., Czas plemion. Schyłek indywidualizmu w społeczeństwach współczesnych, przekł. M. Bucholz, Państwowe Wydawnictwo Naukowe, Warszawa 2008.

McLaren P., Antystruktura oporu, [w:] Nieobecne dyskursy, Z. Kwieciński (red.), cz. 2, Wydawnictwo Uniwersytetu Mikołaja Kopernika, Toruń 1992. 
McLaren P., Rytualne wymiary oporu - błaznowanie i symboliczna inwersja, [w:] Nieobecne dyskursy, Z. Kwieciński (red.), cz. 1, Wydawnictwo Uniwersytetu Mikołaja Kopernika, Toruń 1991.

Melosik Z., Kultura instant - paradoksy pop-tożsamości, [w:] Pedagogika u progu trzeciego tysiąclecia, A. Nalaskowski, K. Rubacha (red.), Wydawnictwo Uniwersytetu Mikołaja Kopernika, Toruń 2001.

Melosik Z., Młodzież w kulturze współczesnej. Paradoksy pop-tożsamości, [w:] Pedagogika i edukacja wobec nowych wspólnot i różnic w jednoczącej się Europie, E. Malewska, B. Śliwerski (red.) Oficyna Wydawnicza Impuls, Kraków 2002.

Płaszczyzna Większościowa Federacji Anarchistycznej: http://www.fa.most.org.pl/ (oficjalna strona internetowa FA, 2001 rok).

Popielski K., Neotyczny wymiar osobowości. Psychologiczna analiza poczucia sensu życia, Wydawnictwo Katolickiego Uniwersytetu Lubelskiego, Lublin 1993.

Rozwój psychiczny człowieka w ciagu życia, M. Tyszkowa (red.), Państwowe Wydawnictwo Naukowe, Warszawa 1988.

Słownik języka polskiego, t. 2, L-P, Państwowe Wydawnictwo Naukowe, Warszawa 1979.

Stasiuk K., Anarchizm jako krytyka kultury w tekstach trzeciego obiegu z lat osiemdziesiatych i dziewięćdziesiątych, „Kultura i Społeczeństwo” 1999, nr 2.

Szczukiewicz P., Rozwój psychospołeczny a tożsamość, Wydawnictwo Uniwersytetu Marii Curie-Skłodowskiej, Lublin 1998.

Tokarczyk R., Wspótczesne doktryny polityczne, Zakamycze, Kraków 2002.

Waluszko J. P., Ruch Społeczeństwa Alternatywnego, Man-Gala Press, Sopot 1992.

Witkowski L., W kwestii oporu o pedagogice polskiej (preliminaria w oczekiwaniu na przełom), [w:] Przestrzenie oporu w edukacji, E. Bilińska-Suchanek (red.), Pomorska Akademia Pedagogiczna, Toruń 2006.

Wojciechowska M., Współczesna szkoła w opinii uczniów i rodziców, [w:] Tożsamość osobowa a tożsamości społeczne. Wyzwania dla edukacji XXI wieku, T. Bajkowski, K. Sawicki (red.), Trans Humana Wydawnictwo Uniwersyteckie, Białystok 2001.

Zieliński J., Czy w Polsce anarchizm ma rację bytu?, Zielona Góra 1998 - przedruk w formie broszury.

\section{SUMMARY}

\section{Obediently of disobedience - the anarchist in school}

Disobedience is one of the features that distinguish anarchists from other youth subcultures. It is also characterized by the attitude towards school. The basic value here is widely understood freedom. The analysis of anarchist literature suggest that anarchist students in school may use different forms of resistance, contesting the power and the importance of school culture.

The results of my research conducted among students of secondary schools, have shown otherwise. The respondents accept the existence of school and the compulsion to attend it, regardless of the degree of involvement in the movement, pragmatically, as the level of education necessary to fulfil further life plans. They perceive the school as an institution, through which one must pass at the lowest cost. Their criticism of the school and its culture manifests itself only at a declarative, not active level.

KEYWORDS: resistance, youth, anarchists, school. 